\title{
Comentário V
}

\section{passado tem um futuro?}

Elias Thomé Saliba ${ }^{1}$

artigo do professor Manoel Luiz Salgado Guimarães faz um diagnóstico percuciente das atuais concepções de história e passado - e de suas vicissitudes -, num cenário marcado por uma alteração radical nas concepções de tempo e em seus regimes de historicidade. $\bigcirc$ aumento da capacidade técnica de armazenamento do passado e a velocidade temporal que limita e modifica radicalmente a experiência histórica são o primeiro e mais visível sintoma do paradoxo da atual conjuntura, que surge nas duas dimensões de regimes distintos de produção cognitiva do passado: uma história de circulação massiva e uma história de corte acadêmico. A estas duas dimensões - indicadas por Beatriz Sarlo e que não implicam em hierarquização de qualidade do que é produzido -, Guimarães acrescenta (a nosso ver, de forma pertinente) uma história com finalidades pedagógicas - matéria de ensino nas escolas ou objeto de políticas públicas. Aumentamos a capacidade técnica de armazenamento do passado, mas a velocidade e a aceleração da vida acabam por estiolar nossas concepções de tempo, incluindo a concepção do próprio passado, uma premissa indispensável à própria idéia de História. E não há como negar que isso vem afetando as três dimensões da história: a história de circulação massiva, a historia de corte acadêmico e a história com finalidades pedagógicas.

E não há como discordar da correção do diagnóstico. Pelo lado técnico, contudo, o aumento da capacidade de armazenamento provavelmente está nos conduzindo também a uma visão cada vez mais volátil do passado. Mas há diagnósticos mais recentes bem mais sombrios. Fotografia infravermelha, análise de DNA, arquivos digitais, radar espacial: com o advento da era da informática, historiadores e arqueólogos parecem ter descoberto o Santo Graal da memória infinita, com possibilidade de acesso imediato e permanente a quantidades virtualmente ilimitadas de informação. Correto? Não. Assim como se acelera o ritmo da mudança tecnológica, muda também a velocidade com

\footnotetext{
1. Docente do Departamento de História / Faculdade de Filosofia, Letras e Ciências Humanas / Universidade de São Paulo. E-mail: <etsaliba $@$ yahoo.com.br>.
} 
que cada nova geração de equipamentos suplanta a anterior. A velocidade e a capacidade de um chip de computador vão dobrar a cada 18 meses: esta lei de Moore, trivial no campo da informática, traz conseqüências paradoxais para a preservação do passado: somos capazes de registrar mais informação do que em quaisquer outros períodos da história, mas também os mais capazes de perder informações. Pode-se contar que informações gravadas por meios eletrônicos, em fitas ou CDs, durem cerca de vinte anos e, depois desse tempo, tendem a estragar-se. Se as informações não forem copiadas ou re-copiadas regularmente numa nova base, certamente ficarão inacessíveis; também seremos incapazes de acessar grande parte da informação produzida em décadas recentes, porque software e hardware mudam muito rapidamente. Somos confrontados diariamente com tal desafio: quem já não perdeu informações gravadas em discos ou suportes para os quais não há mais equipamentos compatíveis? Seremos forçados a criar "Museus de Tecnologia Obsoleta", com aparelhos que desapareceram, só para recuperar arquivos perdidos? Como a sociedade vai preservar sua memória, se o excesso de informação ameaça abarrotar os bancos de dados, condenando-nos a um eterno presente? Embora as reflexões de Guimarães avancem para um diagnóstico que ultrapassa esta dimensão puramente técnica de suportes e registros, seria interessante acrescentar alguns elementos que interferem decisivamente em nossas concepções.

Seria possível um projeto de patrimonialização deste mesmo passado, quando nossa própria noção de registro temporal se vê radicalmente corrompida? Guimarães cita o exemplo de Berlim, transformada numa "cidade para historiadores", e na qual "ocupam-se os vazios com a lembrança possível de um passado que se quer superado, mas, também, com investimentos para um recordarse no futuro". É um exemplo notório, a ser seguido, como uma espécie de paradigma, por instituições responsáveis por gestão pública, mas também raríssimo - quase uma exceção no panorama geral de experimentação do passado. Como contraponto, vejam-se as surpreendentes reportagens de Alexander Stille, em The future of the past. Da Biblioteca do Vaticano aos ladrões de túmulo em Aidone (Sicília); da preservação do latim aos impasses para manter - Parque Ranomafana (floresta de Madagascar), vamos percorrendo um roteiro abarrotado das controvérsias e contradições que cercam o que antigamente designávamos, com certa pompa, de "herança cultural da humanidade". $\bigcirc$ capítulo que Stille escreve a respeito da cultura da cópia na China revela peculiaridades da visão oriental quanto à preservação material do passado. A língua chinesa possui dois significados diferentes para a palavra cópia: fang zhipin é uma daquelas réplicas que podemos comprar em lojas de museus; já fu zhipin é uma cópia de alta qualidade artística, que pode perfeitamente substituir o original. Mas como não existem fiscais nesta alfândega mundial de relíquias da história, os ocidentais continuam confusos e, quase sempre, compram fang zhipin pelo preço de fu zhipin! Obviamente não se trata apenas de mera questão mercadológica, mas de permanência de uma modalidade de concepção cultural que nem sempre é contemplada em projetos de patrimonialização. 
Já a reportagem de Stille sobre a Esfinge e as pirâmides constitui uma das mais bem documentadas - e melancólicas - sínteses sobre o tema. Desde que a atriz Shirley Maclaine - anos atrás - passou uma noite meditando dentro da Esfinge, inúmeros autores (conhecidos por "piramidiotas") inventaram milhares de interpretações fantasiosas envolvendo as pirâmides, baseados em medidas imprecisas dos monumentos, cujas dimensões têm sido cada vez mais reduzidas pela deterioração e pilhagem. Por meio de informações fantasiosas, criou-se, pela internet, um movimento que mistura misticismo de segunda categoria com pacotes místicos para as pirâmides. A coisa seria cômica se não implicasse chegar a dizer que o complexo de Gizé teria sido construído há 70 mil anos (uma rigorosa "bobagem") e que existiria uma pirâmide de cristal enterrada sob a Grande Pirâmide! Quando o rico contexto histórico e os detalhes sutis dos registros arqueológicos desaparecem, torna-se muito mais fácil reescrever a história, criar fantasias e impô-las a pessoas incultas e crédulas.

Por outro lado, o turismo globalizado também tem alterado radicalmente os padrões de convivência com o patrimônio passado. Anos atrás, já comentávamos, num dossiê publicado nestes mesmos Anais, o processo avassalador e crescente de disneyficação do passado. Em Albanella, a $20 \mathrm{~km}$ do templo de Paestum e $60 \mathrm{~km}$ do templo de Velia, vai ser construído um parque ecológico chamado Mela Hellas (que, afinal, significa Magna Grécia), com um templo falso, mas íntegro, todo em concreto revestido de travertino. Os que defendem a iniciativa pensam em um fluxo turístico maior do que aquele dos templos verdadeiros, já um tanto desbeiçados, permitem. Os que a atacam, argumentam que, a poucos quilômetros dali, há um templo verdadeiro, do século IV-V a.C. - e que ninguém pensa em trazê-lo à luz. Mas a construção já começou e o processo é irreversível. Tão irreversível que já provocou a reação, entre conformada e cínica, de Umberto Eco:

Como seria produtiva uma Uffizylândia situada na periferia de Florença, com reproduções perfeitas dos quadros da Galleria degli Uffizie Já que as pessoas se amontoam diante do Palazzo Vechio para admirar um David que não é o original (mas não sabem disso, ou não se preocupam), por que não deveriam ir à Uffizylândia? Imaginem quantas pessoas ficarão muito mais satisfeitas com o falso templo de Albanella, inteirinho e reluzente, do que com aquele que sobreviveu com tanta dificuldade em Paestum? (ECO, 2007, p. 82)

Tudo isso parece longe da sutileza e da profundidade dos argumentos de Guimarães. $O$ belíssimo exemplo de Corinne - personagem de Madame de Staël, no seu olhar oitocentista sobre Roma-, que ele nos faz recordar, é altamente elucidativo e inspirador. Também a sua caracterização erudita do olhar dos colecionadores e antiquários esclarece nossa dependência em relação à cultura historiográfica oitocentista. É muito oportuna a lembrança do texto inaugurador de Walter Scott - que serviu como ponto de partida às reflexões clássicas de Ranke. Mas seria também pertinente resgatar as considerações de Momigliano sobre as relações entre a cultura antiquária e o surgimento da crítica histórica. (MOMIGLIANO, 2004, pp.85-1 18). Mais recentemente - centrando-se na analise do filósofo-antiquário Francesco Robortello - Carlo Ginzburg retornou 
ao mesmo tema, sugerindo que a trajetória vigorosamente delineada por Momigliano deveria ser antecipada para o século XVI. (Ginzburg, 2007, pp. 17 39). De qualquer forma, concordamos que é necessário superar o projeto colecionista e antiquário em relação ao passado - mas a visão de mercado, que impregna a história de circulação massiva, e o turismo globalizado não estão, ambos, apenas a vestir com novas roupas estas mesmas concepções?

Outro sintoma apontado por Guimarães - este já fortemente relacionado a uma visualização do passado - nos conduz ao importante tema da relação entre o escrito e a imagem. Inspirando-se na caracterização da "decisão mosaica", de Assmann, Guimarães escava o sedimento mais fundo do espaço cultural que forjou a antinomia escrito/imagem. "Recuperada em sua dignidade, a imagem, ao lado do escrito, assume diferentes significados na cultura moderna como possibilidade de visualização do passado, como forma de oferecer à visão o invisível do passado". Esta assertiva de Guimarães é pertinente, muito bem formulada e altamente inspiradora - mas, também inquietante: como chegar a esta visualização do invisível, num cenário de renitente crise das teorias ou na ausência de um princípio explicativo forte e com capacidade inclusiva? $\bigcirc$ próprio Guimarães admite tal inquietação quando, no final do artigo, pergunta:

Correríamos nós o risco de perder a profundidade histórica, tornando essa ida ao passado um mero jogo de consolo para um presente experimentado como pouco atraente? A história [...estaria] então, a serviço não de uma inspiração para a ação para a recriação do mundo humano, mas tão somente para o reencontrar-se no passado, reafirmando uma identidade do presente, que parece não querer passar? (p. 30)

Não estamos longe de partilhar plenamente destas inquietações.

Também partilhando dessas perplexidades - e partindo também de uma certa leitura da "decisão mosaica" - Russell Jacoby, em ensaio recente, propõe a deflação de todos os sentidos atribuídos às idéias utópicas e resolve botar um pouco de ordem na confusão que se estabeleceu em torno do tema. Começa pela distinção entre utopias projetistas e utopias iconoclastas.

As utopias projetistas descrevem com o máximo de exatidão o ideal da cidade utópica, mas, como nunca indicam os meios para se chegar a tal projeto, acabam por transformar o futuro num ícone da verdade, que nos aprisiona e nos restringe ao presente. Da mesma maneira que Thomas More, o grande iniciador desta linhagem, os "projetistas" acreditam num relato fiel e completo do passado, transferindo esta crença ingênua na direção de um futuro pleno de sentido e totalmente delineado. Acabam por enredar-se num sistema lógico fechado, que postula as leis da história e acaba por conduzir a totalitarismos de todas as espécies.

Já as utopias iconoclastas fazem jus ao nome: seguindo a tradição judaica, que proíbe representar (ou nomear) Deus, elas se recusam também a delinear o futuro através de uma imagem. $\bigcirc$ poeta Paul Celan, que sobreviveu a um campo de concentração nazista e suicidou-se aos 49 anos, sublinhou a seguinte frase do Talmude: "Aquele que pronunciar o Nome perderá a sua parte 
no mundo futuro". Algo parecido está também definido no Êxodo, quando este se refere à proibição em relação aos ídolos: "não farás para ti ídolos, nem thes prestará culto". O clássico dos iconoclastas judeus é $\bigcirc$ Espírito da Utopia, de Ernest Bloch, escrito em 1918 - um livro que ataca a tirania das imagens, explorando a interioridade, a música e a alma. $\bigcirc$ futuro não pode - e não deve - ser descrito concretamente, ele só pode ser abordado por meio de pistas e parábolas e, quase poderíamos dizer, é possível ouvir o futuro, mas não vê-lo.

$\mathrm{Na}$ lista dos iconoclastas entram nomes como Walter Benjamin, Theodor Adorno, Gustav Landaver e Ludwig Wittgenstein. Eles não formaram um grupo, mas possuíam algumas afinidades eletivas: como judeus que eram, em sua grande maioria, não nomearam nem representaram Deus - e nem inventariaram o futuro. A famosa declaração de Adorno de que "escrever poesia depois de Auschwitz é uma barbárie" deu o que falar - mas a idéia também seria uma parte da sua própria elaboração do tabu sobre as imagens. O absoluto - incluindo a violência absoluta - não pode ser compreendido, ele exige o retraimento ou a recusa - a única atitude que preserva a possibilidade da libertação. Wittgenstein também comparece, pois, de modo análogo, a linguagem também seduz pela ilusão de capturar a verdade: "O que não se pode falar, deve-se calar" (p. 129) - é a frase seminal com que Wittgenstein encerra o seu famoso Tratactus.

Nas condições de produção cognitiva da história, seria possível uma inteligência da imagem que tornasse visível o invisível? Também é uma brecha que parece lidar com algo quase impossível, pois contraria frontalmente um desejo incoercível de nossa época: o gosto pelas imagens. Uma sociedade obcecada pelas imagens. Uma cortina de imagens nos circunda, da manhã à noite, da infância à velhice. A própria palavra se retrai e subordina-se à visualização, ou perde o sentido sem a imagem. "Tudo está subordinado" escreve Jacques Ellul - "à visualização e nada tem sentido fora dela, pois vivemos uma era da visualização extrema". Extravagâncias em multimídia conduziram ao limite nossa predisposição fisiológica para a tirania da imagem. Num livro estarrecedor, Derrick de Kerchkhove estudou os efeitos da TV no sistema nervoso humano - e chegou à conclusão que a TV fala ao corpo e não à mente. A nova cultura cibernética e digital tem o seu calendário próprio e será quase inevitável que aceitemos, cada vez mais, a predominância de uma cultura visual sobre a cultura letrada. Kerchkhove tem um conclusão otimista, que lembra o seu mestre Marshall Mcluhan: a ignorância será uma comodidade, porque os indivíduos não programados terão uma vantagem funcional sobre os programados: serão mais flexíveis, menos presos a velhos condicionamentos para aprender tecnologias.

Não sou tão otimista. Continuamos a viver uma intoxicação de imagens. Pode ser a idade, mas recuso-me a ver a coisa como uma simples troca de gerações: o consumo das imagens saturou a capacidade de absorção do nosso sistema nervoso e chegamos ao limite do insuportável. Mas, tomara que o lúcido artigo de Manoel Salgado Guimarães nos sirva, a todos, de consolo e incentivo. 